\title{
Improving Students' Writing Skill in Descriptive Text by Using Outdoor Activity
}

\author{
Sri Suharmi \\ Mts Sudirman Kopeng Getasan, Kab. Semarang \\ sri.suharmi@gmail.com
}

\begin{abstract}
This study is a classroom action research. The general objective of this study is improving students' writing skill through outdoor activity. While the specific objective of this research are (1) whether or not outdoor activity can increase the students' writing content of descriptive text of the second year of Mts Sudirman Kopeng Getasan. (2) it describe whether the outdoor activity can improve the students' writing skill in developing paragraph. This classroom action research was conducted at MTs Sudirman Getasan. The procedure of the research consisted of planning, action, observing, and reflection. The observation during the process of English teaching and learning was helped by the collaborator. In this research, the writer acted as a practitioner. The test was in the form of pre-test and post -test conducted in cycle 1, cycle 2 , and cycle 3 . The research result were: (1) using outdoor activity as a method can improve students' writing skill, its proved with the student's improvement score. The mean score of the pre-test of the students was 57 (very poor) and the mean score of the post- test 70 (good). The mean of the post-Test is higher than the mean of the pre-Test $(64.53>56.56)$, the mean of the post-test in cycle 2 is higher than mean of cycle 1 $(70.59>64.53)$ and the mean of the post -Test cycle 3 is higher than cycle $2(74.56>70.59)$. the proven result of the implementation was $75 \%$. (2) The effectiveness of using outdoor activity in improving students' writing skill is proved from the t-test and t-table in cycle $1(9.67>2.042)$ which the score of t-test was higher than the score of t-table and the
\end{abstract}


result of t-test and t-table in cycle $3(15.11>2.042)$ also showed that the score of t-table.

Keywords: outdoor activity, writing skill, descriptive text

\section{Abstrak}

Skripsi ini merupakan penelitian tindakan kelas. Tujan secara umum dari penulisan adalah untuk mengetahui kemampuan siswa dalam menulis melalui kegiatan di luar kelas. Sedangkan tujuan secara khusus dari peneliatian adalah (1) apakah kegiatan diluar kelas mampu meningkatkan kemampuan siswa dalam menulis descriptive teks siswa kelas 2 Mts Sudirman Getasan (2) untuk mendeskripsikan apakah kegiatan di luar kelas meningkatkan kemampuan siswa dalam menulis dalam menyususn paragraph.Penelitian ini dilakukan di MTs Sudirman Getasan. Prosedur penelitian terdirir atas Planning, action, observation dan reflection. Data diperoleh dari hasil tes, observasi, wawancara dan dokumentasi. Selama kegiatan penelitian penuis dibantu oleh kolaborator dan peneliti bertindak sebagai praktisi. Tes yang diberikan kepada siswa pada saat siklus 1,2 dan 3. Sedangkan penelitian ini menghasilkan: (1) Kegiatan di luar ruang sebagai metode, dapat meningkatkan kemampuan siswa dalam menulis, ini terbukti dengan perolehan skor siswa dengan skor rata-rata pre- tes 57 ( sangat buruk), rata-rata pos-tes 70 ( baik). Rata-rata nilai pos tes di siklus 1 lebih tinggi dari pre tes $(64,53>56,56)$ Sedangkan rata-rata dari pos tes disiklus 2 lebih tinggi dar siklus $1(70,59>56,56)$ dan rata-rata dari siklus 3 lebih tinggi dari siklus 2 (74,56>70.59). Hasil pembuktian dari implementasi metode kegiatan luar adalah $85 \%$. (2) keefektifan dari penggunaan kegiatan luar ruangan dalam meningkatkan kemampuan siswa terbukti dari hasil t-tes dan t-table di siklus $1(9,67>2.042)$, hasil t-tes dan t-table di siklus 3 lebih tinggi $(15,11>2,042)$

Kata kunci: Kegiatan Luar Kelas, Keterampilan Mengarang, Teks Deskriptif 


\section{Introduction}

English is one of the subject matter learned by students that are given any educational level, such as elementary and upper intermediate level. It covers four language skill that must be mastered if someone wants to be successful in studying English: listening, speaking, reading and writing.

One of those four components that must be thought by the teacher is writing skill. It has always important place in most English language course. One of the reasons is that more people need to learn writing in English for occupational or academic purpose. To write well people must have good capabilities in writing. More ever, people want to write the essay or story must know the steps in writing process and aspect of writing. The writer must be able to organize the ideas, to construct the sentences, to use punctuations and spelling well. Besides that, they must be able to arrange their writing into cohesive and coherent paragraph and text that is why writing is a very complex skill. Thus, it is not easy task for English teacher to teach it. Teacher often find difficulties in teaching writing.

Just like the teacher in the second year of Mts Sudirman Kopeng, Getasan who finds many problems to provide the student with that skill. According to pre interview of this research that was held on $7^{\text {th }}$ of January 2015, the writer found some difficulties that faced by the students in writing. In doing pre interview the writer asked some questions to the teacher, the question are about general condition in teaching learning process of English material especially in writing subject, about the studets and their participation and also the strategy that used by the teacher in writing. The teacher gives some arguments, which 
are as it knows that writing skill is considered difficult by the students for some reasons, those reason are that the students usually get difficulties in starting their writing. That well cause many student waste valuable time just for getting started. Besides, the student have problem to develop the paragraph with a good structure and text component. They are confused to develop paragraph because they have not inspiration to develop it and lack of linguistic competence and rhetorical styles that lend to texture component. They have less understanding about the notion of text context and genre which have relationship with writing activities.

Besides the pre interview, the writer also saw the teaching process, some of the students walking around the class, looking out of the window while learning process are running. The student were seem bored to study indoor or in class, they need inspiration to write that make them face a real concept not only imagination that the teacher brings to the class. Brings some imagination only give some little help to the students in the class to build a good sentences, by bring the real things or come to the real things the students will get more than a sentences to write.

Based on the problem identification in the field of research, the writer conducts an action research using outdoor activities. It is expected that the writer is a teacher will be able to motivate the students to learn the materials, pay attention to the lesson and make them not to get bored.

Outdoor activities usually mean activities done in nature away from civilization, out of the house or building. Outdoor activity is an activity that can be done by people to lose the feeling of boredom. It is more interesting than indoor activities, because these activities are conducted outdoor. When we are being outdoor, we can get more motivation to learn something. Although outdoor activity makes noise, it 
needs power and physical energy (Patmonodewo, 2003: 113). The sense of peace and pleasure is the children's experience when they take in the fresh air. In outdoor the children get inspiration for their writing because they can see the object that they will describe, beside at outdoor they feel relax. While children spend outdoor every day, children have many ways to enrich the objective of the course and support children development and acquisition.

Based on the previous reasons, the writer interested in conducting a classroom action research entitled Improving Students' Writing Skill in Descriptive Text by Using Outdoor Activity (a Classroom Action Research) of the Second Year of MTs Sudirman Kopeng, Getasan in 2015/2016 Academic Year.

\section{Research Methodology}

In this study the writer used Classroom Action Research (CAR). Classroom Action Research is a type of classroom research carried out by the teacher on order to solve problems or to find answer toward context-specific issues. It means that before implementing the Classroom Action Research (CAR), the researcher needs to identify a problem found in the classroom before implementing the CAR.

In accordance to Arikunto (2006: 16) there were four steps to do classroom action research. They are planning, acting, observing and reflecting. The researcher chooses CAR because the researcher finds the problem in learning process that low focus and attention to the learning process. They do not focus on the teacher and keep walking around the class, looking outside through the window seem that they feel bored with the learning process. This problem needs to be solved by using 
Improving Students' Writing Skill in Descriptive Text

by Using Outdoor Activity

appropriate learning strategy through classroom action research.

\section{Research Subject}

The research was conducted at MTs Sudirman Getasan. It was Located at Kopeng Getasan. The subject of this research was the students of class VIII that consist of 32 students in the academic year of $20015 / 2016$.

\section{Research Procedure}

This research applied Kemmis and Mc Taggart's model of classroom action research's method. Arikunto (2010: 137) inform that the principle concept of CAR according to both of those experts consist of four stages, they are planning, acting, observing, and reflecting. The researcher spent two cycles in this research, and started with pre cycle. These stages can be draw as follow:

Figure 3.2 the Classroom Action Research Concept By Kemmis and Taggart

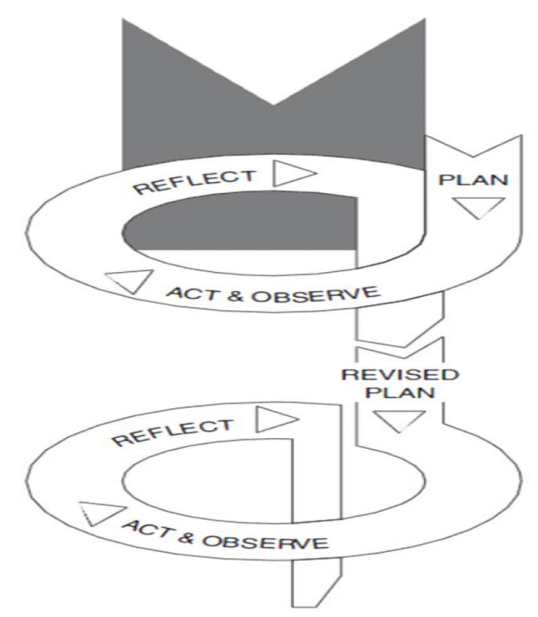




\section{Method of the Collecting Data}

The research uses many data gathering tools. There are 4 methods of collecting data in this study.

\section{Test}

The test consists of some question for the student to be answered. The test implement in the research consist of pre-test and post-test. In this research the pre-test will be given in the first time. The researcher enters the class. Then the post-test was given in the last session in the last teaching implemented. Namely are oral, written and behavior form.

According to Arikunto (1998:139) Test is a series of the questions or exercises and other tools used to measure the skills, knowledge, intelligence, ability or talent possessed by individuals or groups. From the target or object to evacuated. Then it divided the several kinds of tests and other measuring instrument, such as personality test, aptitude test, intelligent test, attitude test, and achievement test.

\section{Observations}

There are two kinds of observation, namely: participant observation, and non- participant observation. In the participant observation the researcher is involved in the object of research action. While non- participant observation, the researcher is only as an observer, she/ he not involve in the activity.

In this study, the researcher uses non- participant observation. Therefore, the researcher observes the activity during the teaching and learning process in detail. The researcher observes the activity 
directly to describe the real situation during English class and note all the phenomena. The researcher does observation to look for information about teaching and learning writing English in the class and the activity implementing outdoor activity. And it is because this observation is non-participation observation, so, the researcher only as an observer.

\section{Interview}

Interview is one of the methods to collect data by using conversation between instructor and respondent. To know the student difficulties in writing procedure text, their opinions and feeling about this method, the researcher uses interview for obtaining data.

\section{Documentation}

In thi sresearch, the writer uses the personal document in documenting all the activity of the research action.

\section{Research Instrument}

Research instruments use to collect data and all the instruments used in this research has been validated by validator to show that all the instruments are valid and can be used in the research. In this study, there are four kinds of research instrument. They are:

\section{Written Test}

Written test uses to know how far the students' competence in writing before and after applying Outdoor Activity strategy. The forms of the test were essay test in this test the teacher will give some grade based on some aspect. Those aspects are grammar, content, organization or 
form and vocabulary. The teacher gives point in each aspect based on the student's ability. The table below shows the example of scoring sheet as follows:

TABLE 3.6 STUDENT'S SCORE SHEET

\begin{tabular}{|l|l|l|l|l|l|l|}
\hline \multirow{2}{*}{ No } & \multirow{2}{*}{ Name } & \multicolumn{5}{|c|}{ Aspects } \\
\cline { 3 - 7 } & Grammar & Content & $\begin{array}{l}\text { Organi- } \\
\text { zation }\end{array}$ & $\begin{array}{l}\text { Vocab- } \\
\text { bulary }\end{array}$ & Mechanics \\
\hline 1. & & & & & & \\
\hline 2. & & & & & & \\
\hline 3. & & & & & & \\
\hline 4. & & & & & & \\
\hline 5. & & & & & & \\
\hline
\end{tabular}

From the score above, the writer conclude a score criteria as a table below:

TABLE 3.7 SCORE CRITERIA

\begin{tabular}{|c|c|c|}
\hline No & Score & Criteria \\
\hline 1 & $89-100$ & Exellent \\
\hline 2 & $79-88$ & Good \\
\hline 3 & $66-78$ & Fair \\
\hline 4 & $46-65$ & Poor \\
\hline 5 & $0-45$ & Very Poor \\
\hline
\end{tabular}


Improving Students' Writing Skill in Descriptive Text by Using Outdoor Activity

\section{Observation Sheet}

Observation sheet uses to know how far the students' motivation before and after applying the strategy. This instrument gives monitor and records the students' involvement during the lesson. In the observation sheet, they are many aspect that are consider focuses, those are: paying attention, activeness in asking question, activeness in responding question and enthusiasm in doing test. In this instrument, the teacher gives point in each aspect based on the situation of students in every cycle.

Table 3.8 Score Criteria of Observation Sheet

\begin{tabular}{|c|c|c|c|c|c|}
\hline \multirow{2}{*}{$\begin{array}{c}\text { Number } \\
\text { of the } \\
\text { Students }\end{array}$} & \multicolumn{4}{|c|}{ OBJECT } & \multirow[b]{2}{*}{ NOTE } \\
\hline & $\begin{array}{l}\text { Pay } \\
\text { attention }\end{array}$ & $\begin{array}{c}\text { Activeness } \\
\text { in asking } \\
\text { question }\end{array}$ & $\begin{array}{l}\text { Activeness in } \\
\text { responding }\end{array}$ & $\begin{array}{l}\text { Enthusiasm } \\
\text { in doing test }\end{array}$ & \\
\hline 1 & & & & & \\
\hline 2 & & & & & \\
\hline 3 & & & & & \\
\hline 4 & & & & & \\
\hline 5 & & & & & \\
\hline
\end{tabular}

\section{Interview Guide}

In this research, the researcher interviews the people that related to this study like the teacher and some of the students. The researcher will interview the teacher to get some information, such as: the difficulties encountered by the teacher in teaching writing during the 
class, the strategies that offered by the teacher to solve students' difficulties in writing descriptive text, things that can disturb the teaching and learning process. And the students writing result by doing this method. Besides that, the teacher also interview the students to know more information about the implementation of this method. The result of this interview were the researcher knew the teacher and students problems faced in teaching learning process, such as: for the teacher; what were the difficulties encountered by the teacher in teaching writing during the class, the strategies that offered by the teacher to solve students' difficulties in writing descriptive text, things that can disturb the teaching and learning process, etc. And for the students; what were the difficulties faced in writing, their feel in the teacher's method and the their opinion about the implementation of outdoor activity, etc.

\section{Documentation}

In this research, the researcher used document as one of the instruments. The researcher collect all the data from the school and teacher documents which are needed in this research like students' writing result in pre - test and post - test and also the students' writing scores in pre - test and post - test. The researcher also took the picture of the teaching and learning process (indoor and outdoor) and used photo as the documentation of this study. Beside that the researcher also prepare some video as documentation.

\section{Method of Analyzing Data}

The research conducts the action research of the teaching writing using outdoor activities in MTs Sudirman Kopeng Getasan. There is 
Improving Students' Writing Skill in Descriptive Text

by Using Outdoor Activity

technique for analyzing data:

\section{Qualitative Data Analysis}

What follows are th steps analyzing data;

- Reducing the Data

This is the first in analyzing the data contain selection process, focusing, and summarizing data from field notes. In this step, the researcher selected, limits, and summarizes the data from the implementation of teaching writing using outdoor activities.

- Displaying the Data

The second step analyzing the data is describing the data in narrative. This step is describing the result of the research which is understandable. The form of displaying is not always in sentences, but can be in the form at table which supports the narrative data.

- Drawing Conclusion

The last step is the researcher draws conclusion and gives suggestion of the research based on data analysis.

\section{Quantitative Data Analysis}

Beside qualitative data the writer uses quantitative data. To know the result of this research the writer uses a formula by comparing the mean score result of pre-test and post-test. In scoring the test, the writer calculates the student's score by using the formula:

- Mean Calculation

$$
\mathrm{M}=
$$


Where:

M : Mean

$\sum F x \quad:$ The total score

$\mathrm{N} \quad$ : Number of student

- Standard Deviation Calculation

Explanation:

$\mathrm{SD}=$ Deviation standard for one sample t-test

$\mathrm{D} \quad=$ Different between pre-test and post-test

$\mathrm{N} \quad=$ Number of observation in sampling

- The Calculation of the T-test

It the mean score result increases, the student's writing skill is considered imposed and vice versa. Finally, by analyzing data from observation, interview, and test the writer is able to draw conclusion whether outdoor activity can improve the student writing skill or not.

\section{Discussion}

In this session, the researcher presented discussion based on all the data on finding of this study. This discussion deals with the research question of this study, these are; does the outdoor activity improve students' ability in writing descriptive text, to what extent is the different improvement the students' ability in writing descriptive text toward the implementation of outdoor activity.

In this case the researcher conducted the data with some instruments and she tried to answer the questions with some instruments; written tests, observation, interview and documentation. The researcher has done the observation three times. 
Improving Students' Writing Skill in Descriptive Text by Using Outdoor Activity

In the first observation the researcher found that the teacher explained about the generic structure of descriptive text. The teacher gave a simple descriptive text and explained about the generic structure of the text. And when the students asked by the teacher to make a descriptive text they difficult to start their writing because most of the students are lack of vocabulary. It is known that from the first observation that most of the students asked to the teacher about the word that would be written. In the second observation and the third observation, the students more confident, more careful, more selective in writing descriptive text.

After describing each cycle, the researcher analyzes the result of all cycle in a table. It used to know the improvement from one cycle into next cycle. The comparative analysis cover of three aspects; they are the procedure of teaching writing descriptive text using outdoor activity, the result, as follows:

Table 4.15

The Result of Teaching - Learning

\begin{tabular}{|c|c|c|c|c|}
\hline Aspect & Before Cycle & Cycle 1 & Cycle 2 & Cycle 3 \\
\hline $\begin{array}{l}\text { The } \\
\text { impleme } \\
\text { ntation } \\
\text { of } \\
\text { teaching } \\
\text { writing } \\
\text { descripti } \\
\text { ve text } \\
\text { using } \\
\text { outdoor } \\
\text { activity }\end{array}$ & $\begin{array}{l}\text { The teacher } \\
\text { just adopted a } \\
\text { traditional } \\
\text { method of } \\
\text { teaching } \\
\text { The material } \\
\text { was not } \\
\text { presented } \\
\text { with media }\end{array}$ & $\begin{array}{l}\text { The teaching } \\
\text { learning process } \\
\text { using outdoor } \\
\text { activity } \\
\text { The material was } \\
\text { presented by } \\
\text { written and real } \\
\text { object. } \\
\text { The procedure } \\
\text { consists of } \\
\text { vocabulary and } \\
\text { grammar }\end{array}$ & $\begin{array}{l}\text { The teaching learning } \\
\text { process used outdoor } \\
\text { activity. } \\
\text { The material was } \\
\text { presented by more } \\
\text { written and seen more } \\
\text { object outside the } \\
\text { classroom. } \\
\text { The writing descriptive } \\
\text { text of teaching learning } \\
\text { process consisted of } \\
\text { vocabulary, and }\end{array}$ & $\begin{array}{l}\text { The teaching } \\
\text { learning process } \\
\text { used outdoor } \\
\text { activity. } \\
\text { The material was } \\
\text { presented by more } \\
\text { written and seen } \\
\text { more object outside } \\
\text { the classroom. } \\
\text { The writing } \\
\text { descriptive text of } \\
\text { teaching learning }\end{array}$ \\
\hline
\end{tabular}




\begin{tabular}{|c|c|c|c|c|}
\hline & & exercises. & grammar exercises. & $\begin{array}{l}\text { process consisted of } \\
\text { vocabulary, and } \\
\text { grammar exercises. }\end{array}$ \\
\hline $\begin{array}{l}\text { The } \\
\text { students' } \\
\text { ability in } \\
\text { writing } \\
\text { descripti } \\
\text { ve text }\end{array}$ & $\begin{array}{l}\text { The average } \\
\text { score } 57 \\
\text { The highest } \\
\text { score was } 70 \\
\text { The lowest } \\
\text { score was } 34 \\
\end{array}$ & $\begin{array}{l}\text { The average score } \\
\text { was } 64 \\
\text { The highest score } \\
80 \\
\text { The lowest score } \\
\text { was } 54\end{array}$ & $\begin{array}{l}\text { The average score was } \\
71 \\
\text { The highest score } 89 \\
\text { The lowest score was } \\
60\end{array}$ & $\begin{array}{l}\text { The average score } \\
\text { was } 74 \\
\text { The highest score } 93 \\
\text { The lowest score was } \\
66\end{array}$ \\
\hline $\begin{array}{l}\text { The } \\
\text { students' } \\
\text { response } \\
\mathrm{S}\end{array}$ & $\begin{array}{l}\text { The } \\
\text { students } \\
\text { gave } \\
\text { positive } \\
\text { response } \\
\mathrm{s} \text { in the } \\
\text { beginnin } \\
\mathrm{g} \text { of the } \\
\text { action. } \\
\text { Some of } \\
\text { the } \\
\text { students }\end{array}$ & $\begin{array}{l}\text { The } \\
\text { students } \\
\text { more } \\
\text { enthusiastic } \\
\text { and } \\
\text { energize } \\
\text { Enough in } \\
\text { the class. } \\
\text { Students } \\
\text { more } \\
\text { cooperative } \\
\text { and } \\
\text { understand } \\
\text { the method } \\
\text { The } \\
\text { students } \\
\text { showed } \\
\text { their } \\
\text { improveme } \\
\text { nt in writing } \\
\text { decriptive } \\
\text { text. }\end{array}$ & $\begin{array}{l}\text { The students more } \\
\text { enthusiastic and } \\
\text { energize in the } \\
\text { class. } \\
\text { Mostly students } \\
\text { were cooperative } \\
\text { in the class and } \\
\text { looked more } \\
\text { braver, more } \\
\text { confident, more } \\
\text { selective and } \\
\text { creative in writing } \\
\text { descriptve text. } \\
\text { The students paid } \\
\text { more attention } \\
\text { during the } \\
\text { teaching learning } \\
\text { process } \\
\text { The students show } \\
\text { their successful } \\
\text { learning }\end{array}$ & $\begin{array}{l}\text { The students } \\
\text { more } \\
\text { enthusiastic } \\
\text { and energize in } \\
\text { the class. } \\
\text { Mostly the } \\
\text { students were } \\
\text { coorpertive } \\
\text { very much and } \\
\text { looked braver, } \\
\text { more } \\
\text { confident, } \\
\text { more selective, } \\
\text { and careful in } \\
\text { writing text. } \\
\text { The students } \\
\text { paid more } \\
\text { attention in } \\
\text { teaching } \\
\text { learning } \\
\text { process. } \\
\text { The students } \\
\text { showed their } \\
\text { sucessful } \\
\text { learning. }\end{array}$ \\
\hline
\end{tabular}

Based on the result above, basically, the discussion is a follows: 


\section{The Implementation of Teaching Writing Descriptive Text Using Outdoor Activity}

The research is conducted in three cycles, every cycle consist of two meeting except the last cycle only held in one meeting. First meeting was held in indoor activity and second meeting was held outdoors. In implementing the action, the researcher used four steps they are planning, action, observing and reflecting in every cycles. The action using method outdoor activity ran well. The students more active and enjoyed the teaching learning process. By using outdoor activity, the students could improve their motivation and it stimulated them to write descriptive text better than before. Therefore, the students got motivation and improve their ability in writing descriptive text.

In the first cycle, the teacher and the writer gave topic "My School". Here the students asked to arrange a jumble sentence. They did it in their group but because they could not finish their task their teacher asked them to make as home work. They could not finish it because they are limited of vocabulary and some of the students did not bring their dictionary.

In te second day of first cycle, the teacher used the method outdoor activity used to finish the assignment given by the teacher. But in applying the technique the researcher found some problems including the limitation of students' vocabulary. To solve this problem, the teacher divided the students into some group so the students could discuss with their friends in the group.

Another problem from this meeting was some disturbance from other class because that time the school yard also used by the other class especially in the volleyball field. To solve the problem, the teacher asked 
some help from the students training from IAIN Salatiga to make the students focus including guided them in writing.

In the second cycle the teacher gave the different topic "Interesting People". Here the researcher used outdoor activity to finish the assignment which given to the students with consideration of the weakness of the first cycle so the teaching learning could be better than before. Here almost all the students brought their dictionary as their resources. In this activity the researcher finds some students who like to make some noise to the teacher called them and give the some warning to not to disturb the other. The teacher tried to monitor all the students in the group. The students looked so active discussing with friands including when they conducted some interview to their interesting teacher.

In the third cycle the teaching learning process only held in one day. The teacher gave topic "Mountain". In this cycle the students look more active and better than the last cycle so there is better improvement from the students. The last meeting the students more familiar with the technique, they more understand where they need to focus on when they was asked to look at something. The students are cooperative more in the group and also in teaching learning process.

\section{The Students' Ability in writing Descriptive Text Using Outdoor Activity}

To know whether the teaching learning using outdoor activity could improve students' writing descriptive or not, the researcher conducted pretest and post-test. The researcher compares the result of the pre- test and post- test. 
The researcher finds that the number of students who increase their writing descriptive text is 25 students. Most of the students who got high score was active in the class, they active in asking question and also answer the teacher's question even though sometime still used in Bahasa.

From the discussion the result of the pre-Test and post-Tes, the researcher could say that outdoor activity could increase the students' ability in writing descriptive. It is proved with the students' improvement score of the tests because mean of post-test in cycle 1 is higher than mean of pre- test $(64.53>56.56)$, the mean of post-test 2 in cycle 2 is higher than mean of post-Test in cycle $1(70.59>64.53)$ and the mean of the mean of post-Test of the cycle 3 is higher than post-Test in the cycle $2(74.56>70.59)$.

The effectiveness of using outdoor activity in improving students writing skill is proved from the result of t-test and t-table in cycle $1(9.67>2.042)$ which the score of t-test was higher than the score of t-table and the result of t-test and t-table in cycle $3(15.11>2.042)$ also showed that the score of t-test was higher than the score of t- table. Here the result of the t-test and the t-table in cycle 2 low $(8.82>2.042)$.

\section{Conclusion}

Based on the result of the research, which aims to develop the students' writing descriptive text using outdoor activity, the researcher made conclusion related to the research question which are stated in chapter I. The conclusions were obtaining through real phenomenon as the researcher did during the observation. The researcher draws some conclusion as follow:

Teaching writing descriptive text using outdoor activity to the 
second year students increases the students' motivation and achivement in writing descriptive text. In implementing this outdoor activity, the teacher explains about the language feature and the generic structure of writing descriptive text. In every meeting, he always remind the students and review the lesson in previous or in the last meeting. The teacher always asked the students to write used their own words and and from the observation, the implementation of outdoor activity could minimize the students' difficulty in writing descriptive text. Beside that it made the student looked happy and interest in joining the teaching learning process, it can be seen from the observation that the students are active anjoy the teaching learning process including when they were in their group, they could express their ideas and most of the students are very enthusiastic to write a descriptive text in outdoor.

The result of the research shows there is an improvement of student's achievement, it known from the result of the pre- test and the post- test. When the students wrote the descriptive text before the action the mean of the students' score is 57 while the mean of the posttest is 70 . In the pre- test the total number of the students that did not pass the passing grade was 22 students. In the first post- test the number is 14 students, the second post- test 3 students and the third posttest or last post- test all the students is pass the passing grade with the lowest score is 66 and the highest score is 93. And the total students those successes in the study also increase, from 17 students up to 29 students. Thus, the improvement of students' writing ability is success and proven.

From the discussion the result of the pre-Test and post-Test, the 
researcher could say that outdoor activity could increase the students' ability in writing descriptive. It is proved with the students' improvement score of the tests because mean of post-test in cycle 1 is higher than mean of pre- test $(64.53>56.56)$, the mean of post-test 2 in cycle 2 is higher than mean of post-Test in cycle $1(70.59>64.53)$ and the mean of the mean of post-Test of the cycle 3 is higher than post-Test in the cycle $2(74.56>70.59)$.

The effectiveness of using outdoor activity in improving students writing skill is proved from the result of t-test and t-table in cycle 1 $(9.67>2.042)$ which the score of t-test was higher than the score of $\mathrm{t}$-table and the result of $\mathrm{t}$-test and $\mathrm{t}$-table in cycle $3(15.11>2.042)$ also showed that the score of t-test was higher than the score of $t$ - table. Here the result of the $t$-test and the t-table in cycle 2 low $(8.82>2.042)$. 


\section{References}

Arikunto, Suharsimi. 1998. Prosedur Penelitian: Suatu Pendekatan Praktek. Jakarta: Rineka Cipta.

Wiraatmaja, Rochihan. 2006. Metode Penelitian Tindakan Kelas. Bandung: PT Remaja Rosdakarya.

Anggraeni, Hayu Raras. 2008. Teaching Writing Narative Genre Using Guided Composition to the Second Year Students of SMP N 1 Gemolong in 2007/2008 Academic Year (A Case Study). Unpublished Research Paper. Surakarta: Muhammadiyah University of Surakarta.

Doughlas, H. Brown. 2007. Principles of Language Learning and Teaching fift edision, San Fransisco State University> Pearson Longman.

Dumais, L.A. 1988. Writing in English. Jakarta: Depdikbud Dirjen Dikti.

Emelia. Riska Tina. 2008. Increasing Students' Writing Skill Using Picture strip Story at the First Year of MTS Ma'hadul Muta'alimin Katerban Ngawi. Unpublished Research Paper. Surakarta: Muhammadiyah University of Surakarta

Fauziati, Endang. 2008. Teaching of English as a Foreign Langauge (TEFL). Surakarta: Muhammadiyah University Press.

Haryanti, Dwi. 1999. Writing Paragraph to Essay. Surakarta: Muhammadiyah University Press.

Maleong, J.L. 1995. Metodologi Penelitian Kuantitatif Bandung: PT Remaja.

Martz, J.T. .2000. School Nture Centres/ Outdoor Classroom Enviromental Education Program. Agriculture Exten. 
Improving Students' Writing Skill in Descriptive Text

by Using Outdoor Activity

Nunan. David. 1991. Practical English Language Teaching. Cambridge: Cambridge University Press.

Oshima, Alice. 1998. Witing Academic English third edisition. USA: Longman

Patmonodewo. 2003. Pendidikan Anak Usia Prasekolah. Jakarta: PT Rineka Cipta.

Reid, Joy M. 2008. The Process of Paragraph Writing. New Jersey: University of Wyoming.

Smalley, Regina L. 2001. Retiming Composition Skills Rethoric and Grammar. USA: Henle \& Henle.

Pardiyono. 2008. Pasti Bisa! Teaching Genre Based Writing. Yogyakarta: C.V Andi Offset. 